\title{
Reflections on the Challenges and Countermeasures of Higher Education Management Informationization against the Backdrop of "Internet +"
}

\author{
Ya-Mei Guan*, Zi-Yi Yu \\ Nanjing University of Finance and Economics \\ Nanjing City, P.R.China, 210023 \\ guanyamei@sina.com
}

\begin{abstract}
The development of China's higher education informatization is in an important period of strategic opportunities. The policy support has been significantly improved, capital investment has been increasing, and the supporting role of information technology in the development of higher education has become more prominent. There is huge room for future development. China's higher education informatization is still in the transition period from large-scale construction to deep application. How to use information technology to transform educational processes, change teaching methods and improve educational efficiency is still a realistic problem. To this end, we must use the Internet thinking to redesign the university, use information technology to increase the selectivity of curriculum, and improve the flexibility of classroom teaching through mixed learning, so as to improve the modernization level of university governance with the support of big data technology.
\end{abstract}

Keywords-Higher education; Management information; Information technology

\section{INTRODUCTION}

Information technology has gone through a long process from the enterprise to higher education. As its influence and scope of influence is being expanding, the IT infrastructure, IT services, and IT resources of the school are becoming more and more important. At the same time, various issues such as risk, security, and return on investment of information technology have become the real challenges faced by colleges and universities. Therefore, it is inevitable to introduce IT governance as a strategy into the construction of information technology in colleges and universities.

\section{DEFINITION OF THE INFORMATIONIZATION OF HIGHER EDUCATION MANAGEMENT}

Teaching, research and management are the three core businesses of higher education. Management informationization is the use of information technology to improve management efficiency and service quality, and reduce management costs. On the one hand, the development of management informationization reflects the continuous improvement and innovation of management means and mechanism for the organization and operation of higher education. On the other hand, it also reflects the continuous deepening and expansion of informationization of teaching and scientific research need support of management informationization and the appropriate follow of service and integration. In the past two years, with the intensive introduction of national "Internet +", big data, new generation artificial intelligence and other strategic policies, the "13th Five-Year Plan" of education informatization has proposed to further promote management informationization, from service education management to comprehensive. Also improve the ability of education and governance. However, although the informatization development of China's higher education management has achieved remarkable results, compared with the level of deep application and integration of innovation in developed countries, there is still a big gap. For example, lag of system and institution, insufficiency of talent supply, complexity of resource integration, and dissatisfaction of user experience. In addition, in order to achieve the interconnection and collaboration between the various departments of the school on the service goal, provide personalized customization services for teachers and students, and communicate with the external society etc, changes in the sense of leadership, standardization, data interconnection and business process reengineering are also necessary.

\section{THE IT GOVERNANCE OF HIGHER EDUCATION MANAGEMENT INFORMATIONIZATION}

\section{A. The origin and development of IT governance in the construction of university informationization}

The advancement of information technology and higher education has enabled educators to see the positive prospects for educational innovation in the generation of information. However, how to better use the information technology to serve higher education has become an important issue for higher education workers to explore for a long time. In the 21 st century, education informatization ushered in a new era of vigorous development. At the same time, the contradictions and frequent problems in the traditional institutions that have been used by educational institutions for a long time have greatly restricted the development of the overall process of higher education and the realization of strategic goals. Under 
this grim situation, it is imperative to transform the old informatization construction management system and observe an effective and innovative development mechanism which is effective and fits the digital trend, and to make effective use of higher education informatization construction. Therefore, this is why the concept come out and be applied to.

\section{B. Higher education IT governance system and governance capacity}

Higher education IT governance is a multi-domain collaborative, multi-group participation in informational decision-making and implementation process, and the complex institutional environment of colleges and universities makes IT governance difficult to implement. Therefore, it is necessary to establish a standardized and transparent IT governance system so that the participants can understand the scope of IT governance, clarify their respective authority, and understand the implementation process of IT governance. On the one hand, the IT governance system can guarantee the implementation of overall goal of university construction from top to bottom. On the other hand, strengthen the normative and directionality of IT governance in the system, so that the university's informatization construction has a realistic and reliable implementation framework. In the ideology, it facilitates the agreement and attention of the interest groups of colleges and universities on the authority and effectiveness of IT governance, builds consensus, and jointly promotes the achievement of information construction and strategic goals.

The construction of higher education IT governance system provides an environment for the construction of information technology in colleges and universities to grow. The IT governance ability of higher education, as a product of the development of IT governance system, to a large extent decides the effect and quality of construction of university information technology. Higher- education IT governance ability refers to the ability which governance entities composed of organizations and personnel carrying out IT governance activities and achieve IT governance goals. Guided by the ultimate goal of IT governance and taking the core concepts of IT governance into account, we can classify IT governance capabilities into strategic decision-making capabilities, systemic integration, coordination capabilities and informationization transformation capabilities.

\section{THE Challenge OF Higher EdUCATiON MANAGEMENT INFORMATIONIZATION UNDER THE BACKGROUND OF "INTERNET+"}

Under the background of the "double first-class" construction of the university in China, we will examine the opportunities and challenges brought by the "Internet + " to the university, efficiently illustrate the unique advantages of the Internet in resource allocation, and then use the Internet thinking to transform the university, which will become strategic choices for development of China's higher level educational informationization

\section{A. Structural innovation of the higher education organization system}

Nowadays, many schools have handed over logistics to the society and adopted new management and business models, which have achieved good results. If the university business is divided into fine divisions, public services such as network operation and maintenance, library services, and college students' practice can be handed over to professional institutions, and even "non-core teaching" can be outsourced to more professional institutions or teachers to complete. This will enable the organization to focus more on its core business and build its core competitiveness. The university uses all excellent social resources to run openly, and focuses on curriculum development and attracting teachers to achieve structural innovation in the university's organizational system. In general, the socialization of public services will become an important trend in the reform of university organizations. In order to achieve a truly open education, we should break through the walls of the campus to think about the development of colleges and universities, integrate the highquality resources inside and outside the campus, and let the "best people do what they do best" and continuously optimize the management service level of colleges and universities. At the same time, we also need to strengthen the sharing of basic data, use big data technology to analyze daily operational data, find the rules behind the data, so that we can provide more precise management services.

\section{B. Co-construction and sharing of higher education curriculum models}

With the rapid development of MOOC, the situation of elite universities monopolizing quality courses has been completely broken. The course will take the lead in breaking through the walls of the university campus to achieve mutual construction and sharing across schools. In the existing colleges and universities, a considerable proportion of schools are comprehensive universities, and the professional settings and curriculum plans between schools have a high degree of intersection. For any course, it is enough to set up the only one best online course in an ideal situation. Students from other schools can take this course online, which can greatly reduce the marginal cost and achieve economies of scale. This requires that colleges and universities cannot pursue a "comprehensive university" that is the same. The university must focus on its own advantages and characteristics, form an advantageous-school-curriculum system, and create its own unique curriculum to provide students with the best quality curriculum experience. For some obviously disadvantaged subject courses, it is entirely possible to use the form of outsourcing of courses to share the quality courses of other schools by informationization [1]. We also need to accelerate the digital transformation of courses and majors, build highquality informatization education and educational resources, actively explore extra-curricular electives, encourage colleges and universities to jointly start classes, and promote the sharing of teachers, courses and mutual recognition of credits. 


\section{Changes in the way of learning in higher education}

Classroom is the main battlefield of higher education informatization, and classroom teaching applications of information technology can never be ignored. With the digitization and wide sharing of the curriculum, colleges and universities should actively promote the in-depth application of information technology in teaching, gradually change the original teaching mode, and realize the transformation from the knowledge transfer to the training based on the ability and quality. We should develop a combination of online and offline learning, encourage students to use the network to carry out independent learning and cooperative learning, improve students' participation in teaching activities, to make students truly become the protagonists of the classroom. In fact, MOOC teaching is just a re-emergence of traditional teaching on the Internet. A teacher faces hundreds of thousands of students in a traditional way for collective teaching, and students are still passively listening. Therefore, colleges and universities cannot rely entirely on online learning. Teachers should redesign the teaching, return the right of study to the students, and let the students become selectors rather than being selected. At the same time, the establishment of flexible years of study and academic system allow students to choose their own time, classroom teachers and more subject courses, to decide the academic process independently. Besides, students can graduate in advance after completing the credits, special circumstances can also apply for temporary interruption and then complete the study in stages.

\section{THE COUNTERMEASURES OF Higher EdUCATION MANAGEMENT INFORMATIONIZATION}

\section{A. Promote the development of higher education to the borderless trend}

With the development of the Internet and new technologies, the boundaries of many business areas have become blurred, therefore, we should break the inherent module, share resources and encourage cross-border innovation. Reengineering the university with Internet thinking is to dismantle the "wall" between the university and the external society, actively absorb the external high-quality resources, optimize the allocation of resources within the university, to achieve the breakthrough of the university from boundary development to borderless development. In the past, universities were run on universities, and internal adjustments were used to drive external development. Now it is necessary to jump out of this situation and attract external resources to instigate internal reforms. Nowadays, universities have shown new changes, for example, new forms of institutions are emerging, cross-institutional cooperation is constantly strengthening, the boundaries between public and private are blurred, and new learning models are constantly innovating. In fact, through the involvement of information technology, MOOC has taken the first step in the socialization of the curriculum. Future information technology will also promote the socialization in business processes, including the socialization of teacher teaching, student learning, and management services.

\section{B. Encourage university teachers to use information technology to innovate teaching}

Technology creates opportunities for educational change, but the key of any new technology's ability to produce good teaching effectiveness depends on the teacher. Information technology does not naturally create educational miracles. It may promote the innovative development of education and may also reinforce the shortcomings of traditional education. At present, China's higher education information infrastructure construction has begun to scale, the education information backbone network has basically formed, the development and application of educational resources has been continuously expanded, and the online curriculum resources construction and sharing system has been initially formed, which already has a good information teaching environment. The next step is to improve the information technology application ability of college teachers, and use this as a cutting point to promote the combination of online and offline hybrid learning, guide students to use the network to carry out active learning, and promote the deep integration of information technology and higher education. Therefore, in order to help them obtain the concepts and capabilities that match the information teaching, priority should be given to the teachers' information technology application ability, the information technology application ability should be included in the teacher evaluation standards, and teachers should be encouraged to use information technology to innovate teaching. On the one hand, according to the professional development rules of teachers, we can create teachers' information technology application ability standards, then put it into the qualifications system for teachers and the qualifications of new teachers, also provide a detailed standards for teachers are competent, so that the more excellent teachers will be better at using information technology for teaching [2]. On the other hand, teachers are encouraged to explore teaching innovation in the information environment. In the education information construction project, the special teacher training funds are matched proportionally, and targeted teacher training is carried out to promote the profound changes in the educational concept and teaching and learning methods.

\section{Improve the governance ability and governance level of higher education informatization}

With the development of information technology in higher education, many universities have accumulated a huge amount of data information. Those include structured data such as personnel, finance, educational affairs, scientific research, and life, as well as unstructured data such as online learning, campus cards, and Internet usage behaviors. However, the development and utilization of existing data resources is still not enough. Many data have been ignored by people and become "silent data." With the maturity of big data technology, we have the ability to "make data speak." The arrival of big data era is suggesting that the essence of today's so-called macro control is no longer a matter of strength, but a vision. To transform the university with Internet thinking, we need to pay attention to the value behind the data. Through in-depth mining of data, we optimize the education management mechanism to provide more accurate services for teachers and students. On the one hand, focusing on macro-level scientific 
decision-making, using big data to improve the modernization level of college governance, big data can surpass the relative static vision of individuals and parts, and it is easier to find problems, possible weaknesses and blind spots, and help managers to fully grasp the daily operation of the school and enhance the scientific nature of decision-making. On the other hand, focusing on the micro-teaching process and its assessment, and clearly describing the previously vague educational activities through data provide evidence support for teachers to improve teaching. Big data is not a magical solution to all problems, because the more data, the greater the noise, but for school education that relies heavily on empirical judgment, big data will still have a positive effect on university governance. It is in line with the characteristics of decentralization and deliberative democracy in university governance.

\section{CONCLUSION}

To sum up, higher education emphasizes IT leadership and university leadership to participate and lead IT governance , strengthens more groups to participate in the construction and adopt responsibilities clear governance processes, advocates unification of university informatization construction and the overall strategic goal, and conforms to the trend of times to promote college informatization change.

\section{ACKNOWLEDGMENT}

(1)This research was financially supported by JiangSu Province Education Science "Thirteenth Five Year" Project (2018) (D/2018/01/36).

(2)This research was financially supported by JiangSu Province Cyan Engineering Excellent Teaching Group.

(3) This research was financially supported by academic degree and master education of Nanjing University of Finance and Economics (Y16006).

(4) This research was financially supported by Jiangsu Province Postgraduate Education Emphasis Project (JGZZ18_034).

\section{REFERENCES}

[1] Ketevan Rostiashvili. Higher Education in Transition [J].European Education, 2011(43):26-44.

[2] Philip G. Altbach. Measuring Academic Progress: the Course-credit System in American Higher Education [J].Higher Education Policy, 2013(14):37-44 